not detected. The question of intergeneric hybrids was also discussed, particularly with reference to the Gramineze.

In Genoa both the University and the city authorities provided generous hospitality. A reception was held at the Palazzo Tursi by the Mayor of Genoa, and the participants had an opportunity of examining there some of the original correspondence of Christopher Columbus. An extensive tour of Genoa and the Riviera de Levante, including Santa Margherita Ligure and Portofino, was provided by the Tourist Organization. The meeting in Genoa ended with a banquet given by the University at Boccadasse. The festivity of this occasion was enhanced by several speeches, including one by Prof. A. Borza in Latin which received an ovation. Prof. Borza, the doyen of the botanists present, took the opportunity of announcing two new species he had discovered-Tutinia gravis and Heywoodia agilis. Since the eloquent Latin descriptions he gave were only verbal and were not therefore effectively published according to the International Code of Nomenclature, steps are being taken to remedy this through other channels.

The next two days were spent on a profitable and enjoyable field excursion-on May 26 to the nature reserve of Portofino, Passo del Bracco and the celebrated Pinus pinea forest at Migliarino, spending the night at Viareggio. On May 27 the excursion went inland to the marble mountains of the Apuane Alps, climbing to the peak of Monte Altissimo. Florence was reached by evening and the final sessions of the symposium were held the next day, May 28, in the
Botanical Institute of the University. In the morning members were shown around the various sections of the Institute, including the newly constructed phytotron and the elegant and spacious herbaria and library. A reception was held in the library dominated by the bust of Philip Barker Webb, whose herbarium, together with the other major collections, make Florence one of the most important centres for taxonomic botany in Europe.

The closing session of the symposium was held in the afternoon when the main business was the report of the Nomenclature Sub-committee, given by the chairman, Dr. N. Hylander. Most of the discussion centred round the validity of publication of the species contained in such works as Gandoger's F'lora Europae. It was decided to make further studies and arrive at an assessment of the number of species involved and the number of changes of name which they might cause before reaching a decision. It was also agreed to circulate lists of nomina ambigua to the members of Flora Europæa with the view of reaching agreement on which of these names should be rejected.

The meeting ended with speeches by Prof. PichiSermolli and Prof. Lüdi. Prof. Borza expressed the hope that it would be possible to hold the next meeting in Rumania. The second Flora Europæa symposium was thus successfully concluded, and co-operation for the future firmly established.

\section{H. HeYwood}

${ }^{1}$ Heywood, V. H. (compiler), The Presentation of Taxonomic Information, Supplement (Alcobaca, 1960).

2 Heywood, V. H. (edit.), Feddes Repertorium, 68, Heft 2 (1960).

' Heywood, V. H. (edit.), Feddes Repertorium, 64, Heft 1, 1 (1961).

\title{
EUROPEAN BROADCASTING CONFERENCE, STOCKHOLM
}

\begin{abstract}
$\mathrm{D}$ URING May 26-June 23, a European conference on "Broadcasting" was held in Stockholm under the auspices of the International Telecommunication Union. The objects of the conference were: first, to revise the 1952 Agreement renched also at Stockholm for the use of the very high-frequency Bands I, II and III for sound and television broadcasting; and secondly, to prepare plans for the future development in the European area of sound broadcasting in Band II, and of television in the ultra-high frequency Bands IV and V. This year the conference was attended by delegates from some forty national administrations, and by representatives of a number of international organizations.

The conference was opened by Dr. Hakan Sterky, director-general of Swedish Telecommunications; and at the first meeting, Dr. E. Esping, technical director of Swedish Telecommunications, was appointed chairman, assisted as vice-chairmen by Captain C. F. Booth and Mr. A. Badalov, leaders of the United Kingdom and U.S.S.R. delegations, respectively.

The technical basis for this recent conference had been formulated in March at a meeting of technical experts of the International Radio Consultative Committee held in Cannes. A detailed report of this meeting provided full information on technical matters, such as the characteristics of transmitters and antenna systems, propagation curves for land and sea conditions, and the signal protection ratios requisite for satisfactory reception of television in
\end{abstract}

the ultra-high-frequency bands from $470 \mathrm{Mc} / \mathrm{s}$. upwards.

The final report adopted by the recent conference at Stockholm will await endorsement by the various national administrations represented. It contains full details of the stations proposed for sound and television broadcasting in the future. In particular, some five thousand stations are listed in the ultrahigh-frequency Bands IV and V, together with the frequencies assigned to these stations to avoid mutual interference during operation. A uniform channelwidth of $8 \mathrm{Mc} / \mathrm{s}$. was proposed for each station, consistent with the adoption of the 625-line standard for the vision signals. In view of the rapid development of television throughout the world at the present time, it was very opportune that this conference was held so that satisfactory plans could be made on a sound technical basis.

One of the participating bodies at Stockholm was the Inter-Union Committee for the Allocation of Frequencies for Radioastronomy and Space Science, which was established by the International Council of Scientific Unions last year. This committee was represented by Drs. H. Sterky, and J. H. D. von der Toorn, by Prof. B. Linblad, and by Dr. R. L. Smith. Rose, secretary-general of the Committee; and it put forward two recommendations designed to protect observations made by radio astronomers in certain frequency bands. One of these sought to secure the free use of the band 606-614 Mc./s. for the radio astronomy service, and was received very sym- 
pathetically by the delegates present at Stockholm, who in a majority of cases agreed to avoid, so far as is practicable, the use of this band for television broadcasting. The second recommendation pointed out the danger of harmonics from certain broadcasting stations in Bands IV and V interfering with radio astronomy observations in the hydrogen band $1,400-1,427 \mathrm{Mc} / \mathrm{s}$. which, in the existing International Radio Regulations, is allocated exclusively for the radioastronomy service. It was recommended that administrations should take all practicable precautions to avoid such interference.

\section{THE BRITISH ELECTRICAL AND ALLIED INDUSTRIES RESEARCH ASSOCIATION}

$\mathrm{T}$

HE annual report of the British Electrical and Allied Industries Research Association opens with a reference to the fact that it records the work of the Association's fortieth year.

Of the work started by the Association in its early days which has contributed substantially to the development of the electrical industry may be mentioned, particularly, research on insulation, on circuit breaking and switchgear, and on the loading capacity of cables. These branches of work still feature largely in the Association's activities.

It was in the third year of the Association's existence that electricity supply undertakings, joining as associate members, initiated the co-operation in research between manufacturers and supply authorities which has continued ever since. Work which is of vital importance to the supply industry and which has been pursued continuously for many years is the determination of the properties of steam at high temperatures and of the characteristics of steel in relation to withstanding high temperatures and stresses.

The present major classifications of the Association's research activities are as follows: insulation and dielectrics; switch and control gear; power plant; insulated cables; overhead lines; surge phenomena ; integrating meters; magnetic materials ; transformers; flame-proofness and intrinsic safety; earthing; safety and circuit problems; rural electrification; heating, cooking and allied problems; electric equipment of automotive systems and communication interference. In addition, there is a small miscellaneous group designated "Unclassified Researches".

The more important results obtained during the year in these various fields, summarized in individual paragraphs of the report, comprise for the most part technological information which is applicable directly in the electrical industry, but there is in addition a substantial volume of new scientific knowledge.

An investigation of the resistance of industrial insulating materials to surface discharges, a phenomenon known as 'tracking', has shown that the resistance to tracking of a poor material is not increased greatly by a substantial increase in the creepage distance.

Measurements relating the temperature of buried cables to seasonal variations of soil properties have been made, and the possible advantages of using special 'backfills' for cable trenches are being investigated.

In relation to flame-proof equipment it has been shown that for some explosive gases obstructions in close proximity to, but outside, the flange gap increase the hazard of explosion, a wrapping of tape to improve dust tightness being particularly dangerous.
Following an investigation of the characteristics of electrical floor-heating for buildings, recommendations have been issued and are now being adopted.

It is also noted that interesting records were obtained last year of the behaviour of the heating system installed for frost protection under the road surface at the Mound in Edinburgh.

Work on vacuum circuit breakers, switches and contactors continues, and it is reported that the vacuum contactor has now reached the stage of commercial development.

In relation to interference arising from industrial radio-frequency equipment, it is stated that all the information has been obtained which is necessary for the preparation of statutory regulations.

In the field of agriculture, reference is made to investigations into methods of drying grain. It appears that for continuous-flow drying the most suitable electrical technique will be infra-red heating.

Among the fundamental researches conducted in university departments under the ægis of the British Electrical and Allied Industries Research Association may be mentioned the work carried on in Liverpool on the theory of conduction in semi-conductors. It is known that the conductivity of germanium increases by several orders of magnitude at fields of $2 \mathrm{~V} . / \mathrm{cm}$. and at liquid helium temperature. This phenomenon, which is often termed 'breakdown', has been shown to be quite unconnected either with instability or with destruction of the lattice. It can, in fact, be predicted theoretically on the basis of earlier work on 'hot' electrons.

Work on gas-discharge phenomena is also in progress with the Townsend ionizatinn chamber on the measurement of ionization and attachment coefficients, and a comprehensive range of data has been obtained for carbon monoxide.

The velocity distribution of cathode particles originating from the spot of a low-current arc between copper electrodes in vacuo has been investigated at Oxford.

At the University of Durham experiments are in progress on collision ionization at ultra-high frequencies.

Perhaps the most noteworthy illustration of the traditional freedom of scientific inquiry occurs under the heading "Astrophysics" in the section of unclassified research work.

Originating in the important technological investigation of are phenomena in eircuit breaking, there has developed the idea of applying fundamental electrical discharge theory to problems on the macroscopic scale of astrophysics. Since 1944 several papers dealing with the development of these hypotheses have been published. 